\title{
Threatened Biodiversity and Traditional Ecological Knowledge: Associated Beliefs, Customs, and Uses of Herpetofauna among the 'Are'Are on Malaita Island, Solomon Islands
}

Edgar John Maeniuta Pollard ${ }^{1 *}$, Randy Thaman², Gilianne Brodie ${ }^{3}$, and Clare Morrison ${ }^{4}$

Author addresses: ${ }^{1}$ Solomon Islands Campus, University of the South Pacific, P.O. Box R241, Honiara, Solomon Islands. ${ }^{2}$ School of Geography, Earth Science and Environment, Faculty of Science, Technology and Environment, University of the South Pacific, Laucala Campus, Suva, Fiji. ${ }^{3}$ School of Biological and Chemical Sciences, Faculty of Science, Technology and Environment, University of the South Pacific, Laucala Campus, Suva, Fiji. ${ }^{4}$ School of Environment, Griffith University, Gold Coast Campus, G24 Parklands Drive, Southport, Queensland 4222, Australia.

*Corresponding author: edgarjmp@gmail.com

Received: April 10, 2015

Volume: 6(1):99-110

Published: August 24, 2015

(C) 2015 Society of Ethnobiology

Abstract: For many societies, including those in the rapidly urbanizing Pacific Islands, local biodiversity is threatened and traditional ecological knowledge (TEK) is in danger of being lost. Herpetofauna, in particular, are globally threatened, along with their associated cultural knowledge and beliefs. The aim of this study was to examine the species richness and conservation status of herpetofauna and associated TEK among the 'Are'Are on Malaita Island, Solomon Islands. Questionnaire surveys were used to collect information about local perceptions and knowledge regarding frogs, skinks, and geckos, as well as their forest habitats. Local informants were distributed equally between sexes and age groups. A total of 18 different species of frogs and lizards were recorded and characterized. Seven distinct cultural uses were identified. Informants above the age of 60 exhibited greater herpetofaunal knowledge, as measured by number of species identified, with males demonstrating knowledge of slightly more species than females. Our results show that action is warranted to document and preserve community TEK in the Solomon Islands as step towards preserving biodiversity and supporting cultural conservation.

Keywords: Herpetofauna, Frogs, Lizards, TEK, 'Are'Are, Solomon Islands

Supplementary Files available at ojs.ethnobiology.org/index.php/ebl.

Introduction

As E. O. Wilson (1992:343) stressed, we are in the midst of the sixth "great extinction spasm of geological time," caused mainly by human degradation of the environment. Thaman (2002, 2008a, b, 2013) has also stressed that there is a parallel "extinction event" relating to the loss of traditional ecological knowledge of biodiversity. Huntington (2000:1270) defined traditional ecological knowledge (TEK) as "the knowledge and insights acquired through extensive observation of an area or species," which is usually shared orally. For thousands of years indigenous peoples have used TEK to survive, build, and maintain their unique cultures (Bennet 2000; FAO 2011; Thaman et al. 2010). With specific reference to ethnobiodiversity, Thaman (2008b:103) has defined such knowledge as "the beliefs, knowledge, uses, customs, management systems, taxonomy and language, that a given culture, including modern science, has for its biodiversity." From this perspective, ethnobiodiversity and TEK provide a strong foundation for successful living in natural and cultural environments and form the 'glue' that encourages social cohesiveness and creates cultural identity as a basis for sustainability (Bennet 2000; Dutfield 2006; FAO 2011; Hviding 2005; Thaman 2009; Thaman et al. 2010, 2013).

TEK is essentially wisdom, knowledge, and information learned through common experience, passed on from generation to generation, and used in decision making, planning, and the management of biodiversity among other resources that are critical and beneficial to life in subsistence communities (Merculieff 2000). TEK is the basis for people's livelihoods and sustainability, as well as their maintenance of cultural, economic, and traditional practices 


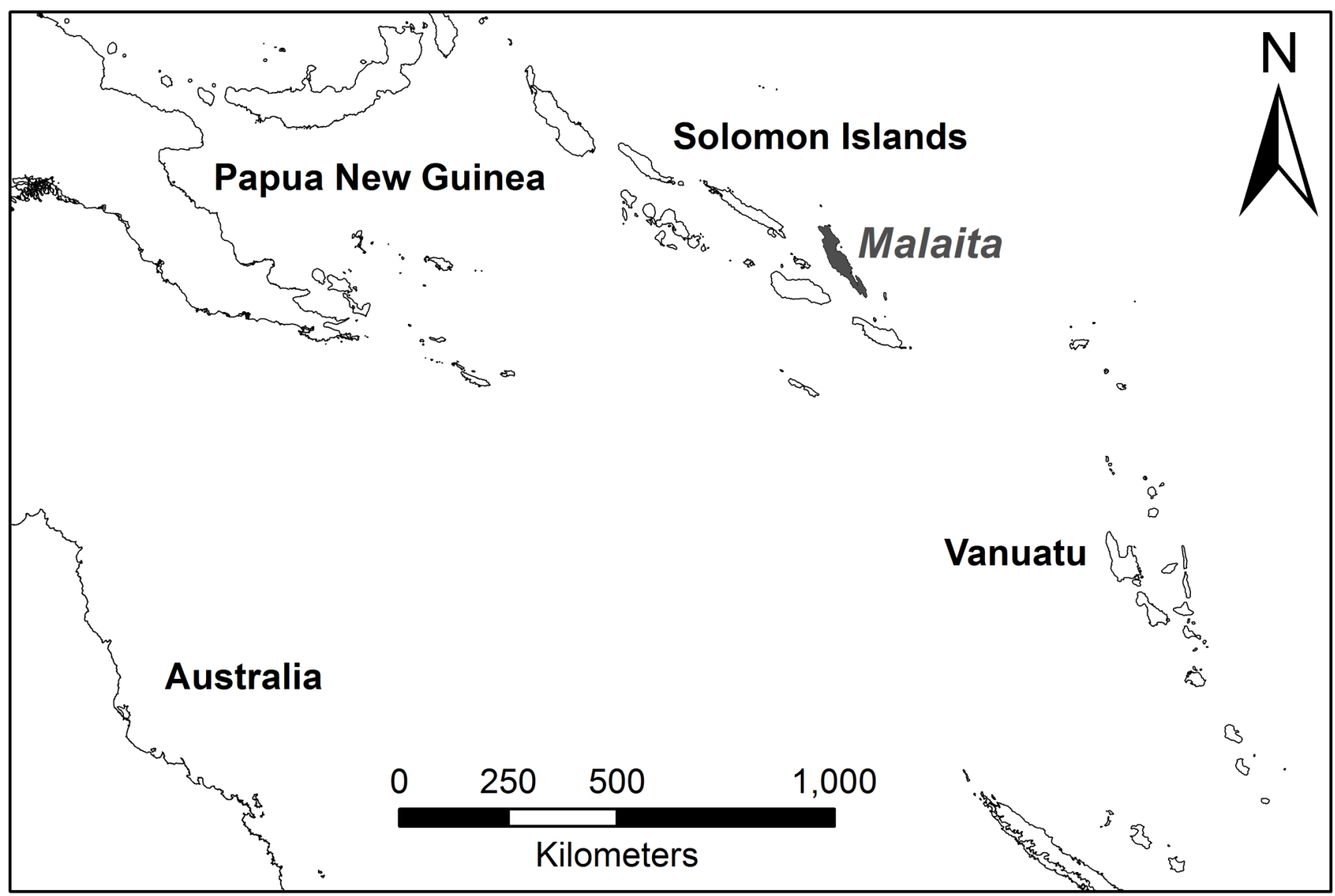

Figure 1. Map showing the location of the Solomon Islands and Malaita.

(Bennet 2000; FAO 2011; Thaman et al. 2010). Thaman $(2002,2013)$ identifies the loss of traditional knowledge as a major threat to biodiversity preservation. Thaman and Hviding (2005) argue that, if the traditional names, taxonomies, uses, and management systems of biodiversity are lost, the impetus for the conservation of these natural resources at the community level is also lost.

In Melanesia, TEK and cultural practices have developed and evolved over millennia, resulting in interactions and relationships with the environment that are based on time-depth, qualitative, holistic, and oral approaches (Caillaud et al. 2004; Merculieff 2000; Walker-Painemilla et al. 2010). Indigenous people have used traditional knowledge, skills, customary laws, taxonomic systems, and traditional practices to sustainably utilize their rich natural resources as a basis for adaptation to change (Lauer and Aswani 2010; Thaman 2013; Walker-Painemilla et al. 2010) and biodiversity conservation (Berkes 2004; Huntington 2000; Walker-Painemilla et al. 2010).
Herpetofauna (amphibians and reptiles) play functionally important roles in energy flow and nutrient cycling in ecosystems and culturally important roles in many societies (Pough et al. 1998). Amphibians, which are usually abundant, are of global conservation concern because of their well-documented widespread decline and often threatened status (Bennett 1999; Bishop et al. 2012; Smith and Rissler 2010; Stuart et al. 2004). Reptiles face a similar fate but are less well documented scientifically (Bombi 2009). Due to the cultural and ecological importance and distinctiveness of herpetofauna, traditional communities, particularly those living in forests, wetlands, or other suitable habitats, commonly have deep knowledge of amphibians and reptiles not shared by scientists and conservationists. This traditional knowledge, the focus of the current survey, can provide a basis for better understanding the cultural and ecological importance and conservation status of herpetofauna. This TEK potentially may be used in collaboration with scientific knowledge for a more 


\section{Malaita Lingual Groups}

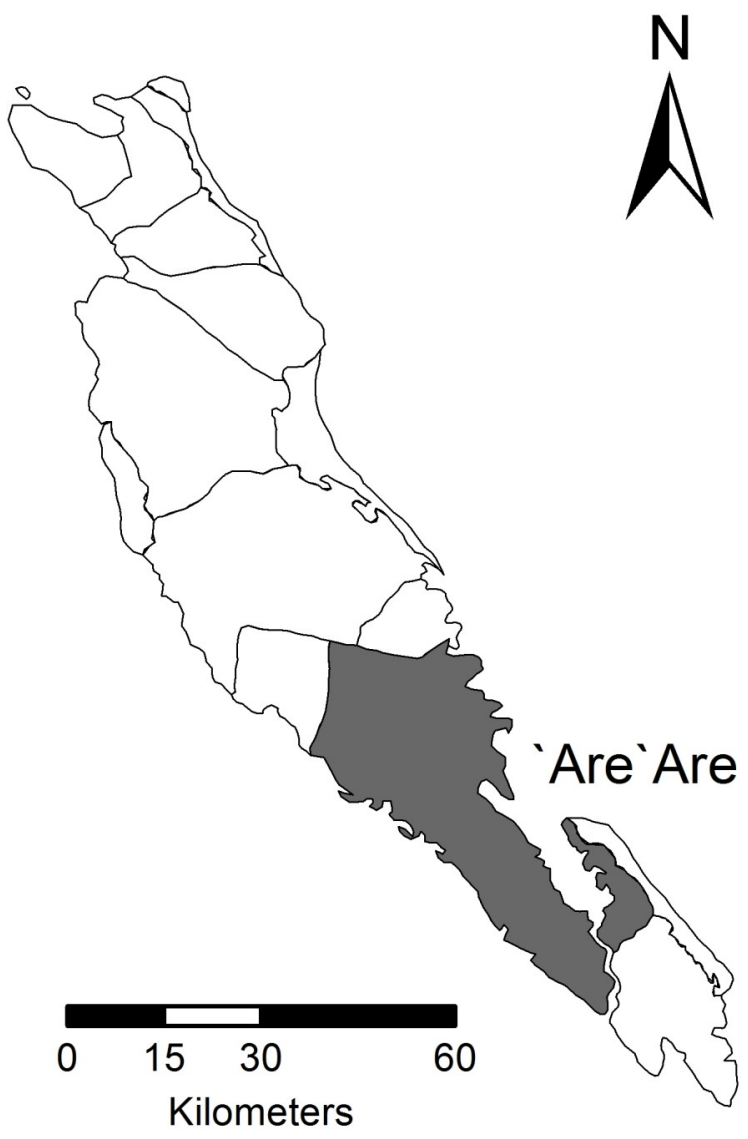

Figure 2. Map of Malaita highlighting the 'Are'Are lingual group.

holistic approach to the conservation management of herpetofauna and other natural resources.

\section{Study Site}

The Solomon Islands, the third largest archipelago in the South Pacific, is located between 6-12 ${ }^{\circ} \mathrm{S}$ latitude and $155-168^{\circ} \mathrm{E}$ longitude (Figure 1) and is composed of a double chain of approximately a thousand islands extending over $1450 \mathrm{~km}$ in a south-easterly direction (Mueller-Dombois and Fosberg 1998). As a nation state, the Solomon Islands are located $1,800 \mathrm{~km}$ northeast of Australia. The total land area is approximately 28,785 $\mathrm{km}^{2}$ (Mueller-Dombois and Fosberg 1998) and the country has rich marine resources with a total marine area of around 1.3 million $\mathrm{km}^{2}$ (Gough et al. 2010).

Malaita Island, the focus of this study, is the third largest and fourth highest island in the Solomon Islands. It is oriented in a northwest to southeast direction about $60 \mathrm{~km}$ northeast of the main island of Guadalcanal (Polhemus et al. 2008). The island is about $190 \mathrm{~km}$ in length and approximately $40 \mathrm{~km}$ wide at its widest point. Dominant landforms include "steep, narrow ridges, fluvial plains, karst mountains, valleys, swamps and coastal landforms" (Moore 2007, PHCG 2008). Lagoons are also a common feature of the island, with the lagoons of the Lau (renowned for its artificial islands), Langa Langa (renowned for its shell money) and 'Are'Are (known for its expansive mangrove forests) constituting some of the most widely recognized features of Malaita province internationally (Moore 2007). Daily temperature ranges from $25^{\circ} \mathrm{C}$ to $32^{\circ} \mathrm{C}$ with high humidity and an annual average rainfall of $5,000 \mathrm{~mm} /$ year (Moore 2007).

With a total land area of approximately $4,200 \mathrm{~km}^{2}$ and roughly 33 persons per square kilometer, Malaita has the highest population density of the Solomon Islands and is home to roughly a third of the total Solomon Islands population of approximately 560,000 (Moore 2007). Almost all of Malaita is still under customary land tenure system and most Malaitans depend on subsistence agriculture (Filardi et al. 2007). Malaita is comprised of 14 language group areas (Figure 2). The 'Are'Are language area in the south covers the largest land area on the island (approximately 25\%). The Tai Ward within the 'Are'Are area was selected as the study location for the present study because (i) it has a relatively low population density and (ii) native vegetation was relatively intact until the commencement of logging operations in the early 2000s, after which subsequent heavy degradation took place throughout the region.

\section{'Are'Are Human Population Demographics}

The age and gender demographics of the 'Are'Are, based on the 2009 national census (SINSO 2011), show a young population (Figure 3), of which 52.9\% is below the age of 20 . This scenario is typical of most of the Solomon Islands in that year. There is an obvious reduction in population numbers between the ages of 15 and 24, probably due to temporary migration due to education or work. The population of older individuals is small, with only $5.8 \%$ over the age of 60 . 


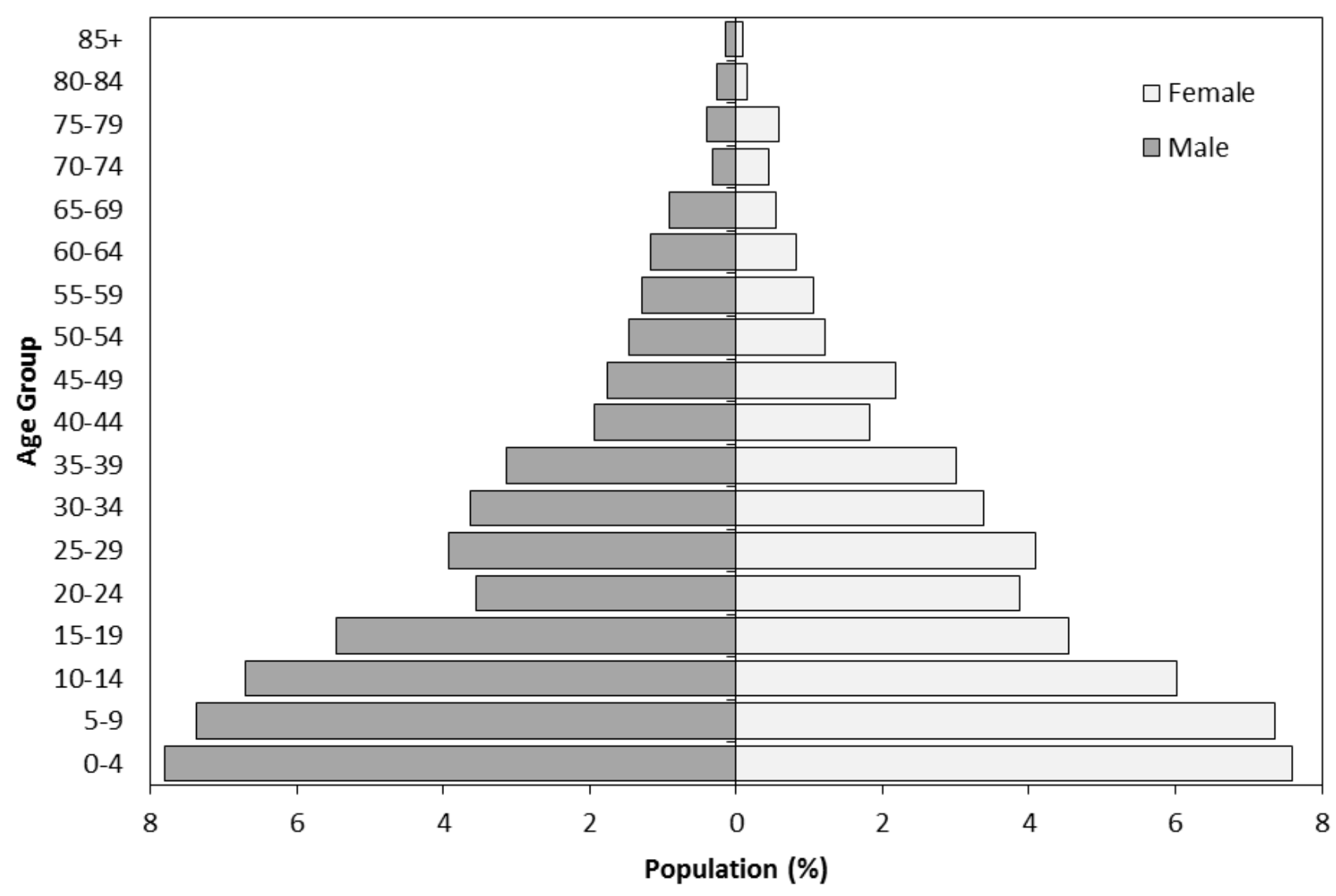

Figure 3. Age and gender demographics of the 'Are'Are, based on the 2009 census (SINSO 2011).

\section{Methods}

Community questionnaires were designed and interviews were conducted to record local 'Are'Are individual's perceptions, knowledge, and uses of herpetofauna (see Supplementary Questionnaire 1). Semi-structured questions were used to solicit information regarding the animals and uses respondents thought were most important. Response information was translated by the authors into the most relevant scientific taxa and assigned to use categories. A pilot study trialling the questionnaire was conducted in August 2011 and the modified survey in September 2011, December 2011, and March 2012. Ten villages within the Tai ward were selected based on ease of access and residents' willingness to participate. With the assistance of an interpreter, a total of 30 interviews were conducted in the ten villages (three per village). Overall, 10 questionnaires were conducted with individuals over the age of 60 , 10 with individuals between 30 and 60 , and 10 with individuals under 30. A gender ratio of 15 females to 15 males was imposed. Survey respondents were selected unsystematically, with the first 3 informants to accept our invitation in each village being interviewed. Herpetofauna species were identified by the authors based on local descriptions by interviewers, photographs taken by the authors and shown to interviewees, and standard taxonomic keys (McCoy 2006; Pikacha et al. 2008). While the questionnaire covered a wider range of issues than those covered in this paper, it included specific questions relating to the TEK of local herpetofauna species (see Supplementary Questionnaire 1).

\section{Results}

Informant's knowledge of frogs and lizards by age and sex A total of 18 distinguishable frog and lizard species were identified and described by interviewees. The average number of frogs and lizards known to informants and the associated TEK they described 
Table 1. Mean numbers of frog and reptile species identified by local community informants during surveys, with standard deviations ( $\pm 1 \mathrm{SD}$ ) and response ranges. $\mathrm{N}=5$ for all age/sex groups.

\begin{tabular}{rll}
\hline Age/Sex Group & Frogs & Lizards \\
\hline Males $<30$ years & $4.4 \pm 0.9(3-5)$ & $7.4 \pm 1.8(5-9)$ \\
Females $<30$ years & $3.6 \pm 0.5(3-4)$ & $4.6 \pm 2.3(2-8)$ \\
Males 30-60 years & $5.8 \pm 2.0(4-8)$ & $6.6 \pm 0.9(6-8)$ \\
Females 30-60 years & $5.2 \pm 3.1(2-10)$ & $7.0 \pm 1.6(5-9)$ \\
Males $>60$ years & $6.4 \pm 1.3(5-8)$ & $7.0 \pm 1.6(5-9)$ \\
Females $>60$ years & $6.4 \pm 2.3(3-8)$ & $6.4 \pm 1.7(4-8)$ \\
\hline
\end{tabular}

varied between sexes and age groups (Table 3). Males and females over the age of 60 demonstrated the greatest knowledge of frogs, with an average of 6.4 species described per informant. Males below the age of 30 showed the greatest knowledge of lizards, with an average of 7.4 species mentioned per informant.

Overall, males of almost all ages demonstrated more knowledge of herpetofauna than females. In the over 60 age group, however, males and females on average identified the same number of species. On average, male informants identified 12.5 frogs and lizards, whereas females identified 10.8.

The most frequently identified species were Discodeles guppyi Boulenger Ceratobatrachidae, Corucia zebrata Gray Scincidae, Rana kreffti Boulenger Ranidae, and Emoia pseudocyanura Brown Scincidae. The least frequently identified were Sphenomorphus bignelli Schmidt Scincidae, Emoia atrocostrata Duméril \& Bibron Scincidae, and Emoia cyanogaster Lesson Scincidae. All identified species had unique names in the local vernacular language (Table 1).

\section{Herpetofaunal cultural uses}

Seven main traditional use categories for the 18 herpetofauna species were identified by the authors from interview responses (Table 1). These were 1) food, 2) trade, 3) totemic (including spiritual importance), 4) medicine, 5) magic (including signs of good or misfortune), 6) folklore, and 7) fishing. Fifteen species were reported to be used as food. Some of these, such as D. guppyi, Batrachylodes vertebralis Boulenger Ceratobatrachidae, C. zebrata, and Cyrtodactylus salomonensis Rösler, Richards \& Gunther Gekkonidae, were reported to be important feast or ceremonial foods. Platymantis solomonis Boulenger Ceratobatrachidae, Platymantis guppyi Boulenger Ceratobatrachidae, and E. cyanogaster were important foods for domestic cats and snakes. Three species were used in trade, with B. vertebralis and P. guppyi being traded as cooked foods and C. salomonensis for the live exotic pet trade overseas.

Five species were used medicinally, with D. guppyi and Ceratobatrachus guentheri Boulenger Ceratobatrachidae used to prevent and/or cure snake and centipede bites. Platymantis guppyi, Litoria thesaurensis Peters Hylidae, and C. guentheri were used to stop bed-wetting in children. E. pseudocyanura was used to prevent facial hair growth. Ceratobatrachus guentheri was also used to treat children with swollen stomachs. Five species were used for magic, with $C$. zebrata and E. atrocostrata being used as sacrifices in ancestral worship and Gehyra oceanica Lesson Gekkonidae and E. cyanogaster used as good luck charms. Four species were mentioned in folklore or stories. For example, it was told that if a person stepped on a B. vertebralis in the forest, a tree may fall on the person. Five species were identified as totems or species of spiritual importance, with P. guppyi and R. kreffti being considered taboo among certain tribes. An evil spirit was said to take the form of Emoia albofasciolatus Gunther Scincidae. Also, the presence of $D$. guppyi and C. guentheri in gardens was reported to increase garden fertility. Five species were also used as bait for fishing, with juvenile R. kreffti being used for catching eels. See Table 2 additional details regarding 'Are'Are uses of herpetofauna species.

\section{Discussion}

The 18 species of frogs and reptiles identified represent $65 \%$ of the known herpetofauna recorded from Malaita (McCoy 2006; Pikacha et al. 2008) and $86 \%$ of the herpetofauna recorded from the 'Are'Are area (Pollard 2014). This high level of species recognition, in conjunction with rich knowledge of their associated uses and cultural values among interviewees, indicates the 'Are'Are community has a strong relationship with herpetofauna. This finding was somewhat unexpected due to the relative rarity of some of these species in the coastal areas currently inhabited by most of the local communities. It also highlights the relative strength of the status of TEK in 'Are'Are society. All 18 species are listed as Least Concern on the IUCN Red List, with the exception of Cyrtodactylus salomonensis, which is listed as Near Threatened due to low area of occurrence and illegal trade of adults (IUCN 2013).

As shown above, males tended to exhibit more herpetofauna knowledge than females, probably 
Table 2. Number of 'Are'Are interviewees who identified each herpetofauna species, by traditional use category, Malaita, Solomon Islands. Key to food use categories: food, species was or is used for human food; trade, species was or is used as an item for barter and exchange; totemic, species considered taboo or sacred to a particular tribe; medicine, species used for curing of ailments; magic, species used as good luck charm, for magic, or sorcery (black magic); folklore, species mentioned in cultural stories or myths; fishing, species used in fishing, mainly as bait.

\begin{tabular}{|c|c|c|c|c|c|c|c|c|c|}
\hline Scientific name & $\begin{array}{r}\text { Local } \\
\text { vernacular } \\
\text { name(s) }\end{array}$ & $\begin{array}{l}\text { No. of } \\
\text { interviewees } \\
\text { who identified } \\
\text { each species }\end{array}$ & Food & Trade & Number of & terviewee & (maximı & Folklore & Fishing \\
\hline $\begin{array}{r}\text { Discodeles guppyi Bouleng- } \\
\text { er Ceratobatrachidae }\end{array}$ & Pari & 27 & 26 & 0 & 3 & 2 & 0 & 0 & 0 \\
\hline Batrachylodes vertebralis & & & & & & & & & \\
\hline $\begin{array}{r}\text { Boulenger Ceratobatrachi- } \\
\text { dae }\end{array}$ & Hahaia & 10 & 10 & 2 & 0 & 0 & 0 & 2 & 0 \\
\hline Ceratobatrachus guentheri & & & & & & & & & \\
\hline $\begin{array}{r}\text { Boulenger Ceratobatrachi- } \\
\text { dae }\end{array}$ & Oripasu & 17 & 17 & 0 & 0 & 15 & 5 & 3 & 0 \\
\hline $\begin{array}{l}\text { Platymantis guppyi Bou- } \\
\text { lenger Ceratobatrachidae }\end{array}$ & Otohao & 14 & 14 & 2 & 5 & 11 & 0 & 0 & 0 \\
\hline $\begin{array}{r}\text { Rana kreffti Boulenger } \\
\text { Ranidae }\end{array}$ & $\begin{array}{l}\text { Pina iki, } \\
\text { Ten ten }\end{array}$ & 22 & 21 & 0 & 7 & 0 & 0 & 0 & 2 \\
\hline $\begin{array}{l}\text { Platymantis weberi } \\
\text { Schmidt Ceratobatrachidae }\end{array}$ & Kori niu & 13 & 13 & 0 & 0 & 0 & 0 & 0 & 0 \\
\hline $\begin{array}{r}\text { Platymantis solomonis } \\
\text { Boulenger Ceratobatrachi- } \\
\text { dae }\end{array}$ & $K a^{\prime} a k a^{\prime} a$ & 4 & 4 & 0 & 0 & 0 & 0 & 0 & 0 \\
\hline $\begin{array}{r}\text { Litoria thesaurensis Peters } \\
\text { Hylidae }\end{array}$ & Taramena & 2 & 2 & 0 & 0 & 2 & 0 & 0 & 0 \\
\hline $\begin{array}{r}\text { Emoia pseudocyanura } \\
\text { Brown Scincidae }\end{array}$ & Ikiko asi & 24 & 22 & 0 & 0 & 2 & 3 & 0 & 0 \\
\hline $\begin{array}{r}\text { Corucia zebrata Gray Scin- } \\
\text { cidae }\end{array}$ & Unu & 26 & 26 & 0 & 0 & 0 & 5 & 6 & 0 \\
\hline $\begin{array}{r}\text { Emoia nigra Jacquinot \& } \\
\text { Guichenot Scincidae }\end{array}$ & Paruparu & 26 & 0 & 0 & 0 & 0 & 0 & 0 & 3 \\
\hline $\begin{array}{r}\text { Gehyra oceanica Lesson } \\
\text { Gekkonidae }\end{array}$ & $\begin{array}{r}\text { Kuma } \\
\text { nima'asu }\end{array}$ & 27 & 21 & 0 & 0 & 0 & 7 & 0 & 0 \\
\hline $\begin{array}{r}\text { Cyrtodactylus salomonen- } \\
\text { sis Rösler, Richards \& Gün- } \\
\text { ther Gekkonidae }\end{array}$ & Rarani & 17 & 15 & 5 & 0 & 0 & 0 & 6 & 0 \\
\hline $\begin{array}{r}\text { Eugongylus albofasciolatus } \\
\text { Günther Scincidae }\end{array}$ & Oru oru & 16 & 11 & 0 & 7 & 0 & 0 & 0 & 0 \\
\hline $\begin{array}{l}\text { Prasinohaema virens Bou- } \\
\text { lenger Scincidae }\end{array}$ & Ikiko ota & 12 & 12 & 0 & 0 & 0 & 0 & 0 & 3 \\
\hline
\end{tabular}

(continued on next page) 


\begin{tabular}{|c|c|c|c|c|c|c|c|c|c|}
\hline \multirow[b]{2}{*}{ Scientific name } & \multirow{2}{*}{$\begin{array}{r}\text { Local } \\
\text { vernacular } \\
\text { name(s) }\end{array}$} & \multirow{2}{*}{$\begin{array}{l}\text { No. of } \\
\text { interviewees } \\
\text { who identified } \\
\text { each species }\end{array}$} & \multicolumn{7}{|c|}{ Number of interviewees (maximum 30) } \\
\hline & & & Food & Trade & Totemic & Medicine & Magic & Folklore & Fishing \\
\hline $\begin{array}{r}\text { Sphenomorphus bignelli } \\
\text { Schmidt Scincidae }\end{array}$ & $\begin{array}{r}\text { Ikiko } \\
\text { maamtoru }\end{array}$ & 8 & 0 & 0 & 0 & 0 & 0 & 0 & 6 \\
\hline $\begin{array}{r}\text { Emoia atrocostrata } \\
\text { Duméril \& Bibron Scincidae }\end{array}$ & Ikiko haho & 6 & 0 & 0 & 6 & 0 & 0 & 0 & 2 \\
\hline $\begin{array}{r}\text { Emoia cyanogaster Lesson } \\
\text { Scincidae }\end{array}$ & Iko ma & 3 & 2 & 0 & 0 & 0 & 1 & 0 & 0 \\
\hline
\end{tabular}

because males spend more time in the forest hunting and collecting, as compared to females, who spend more time in food gardens and at home. The data also indicate a pattern of greater knowledge with increasing age. Older informants had the most in-depth traditional knowledge, thus underlining the potentially threatened state of this knowledge among the younger generation. This observation may also be because some herpetofauna (primarily frogs) are less common near current coastal settlement areas, whereas past settlement areas, where many older informants grew up, were located in inland areas with higher herpetofauna species richness (Pollard et al. 2014). With subsequent migration to coastal sites resulting from movement to Christian settlements for educational and economic reasons (Keesing 1967), less time may be spent by informants in habitats with high herpetofauna diversity. Alternatively, the younger generation may still need time to learn, acquire, and accumulate this knowledge. However, interestingly, younger males had the greatest knowledge of lizards, which suggests that they had sufficient time to gather and learn traditional knowledge. A potential limitation of this analysis, however, is the small sample size employed and potential lack of statistical significance.

\section{Traditional knowledge and use of fauna}

'Are'Are traditional knowledge of 18 species of frogs and lizards (Table 1) includes seven main categories of traditional uses, which are similar in number to those reported in a study by Lohani (2011) in Nepal, with six categories of traditional uses for 49 animals. There was also considerable overlap with Lohani (2011) with regard to use classification types, although Lohani (2011) mentioned the use of animals for weather forecasting but did not mention their use for fishing or trade. Globally, reptiles have been identified as having important traditional medicinal uses (Alves et al. 2008). This is also true for the 'Are'Are, for whom we recorded medicinal uses for one lizard and four frog species. There is a paucity of published literature on traditional knowledge involving frogs and lizards, particularly in the Pacific region, which further highlights the importance of the information collected and presented in the present study. Hviding's (2005) publication of traditional knowledge of marine and coastal natural resources among the Marovo Lagoon people is the only similar work of this nature from the Solomon Islands. In his publication, the local names and associated stories of more than 1,000 species are presented with information on their habitats.

Loss of traditional knowledge

Globally, cultural diversity, including TEK and people's ability to recognize, name, and classify species (i.e. local taxonomic expertise), is threatened by a set of related processes including Westernization, urban drift, and changing lifestyles (Brosius and Hitchner 2010; Caillaud et al. 2004; Walker-Painemilla et al. 2010). As stated by Caillaud et al. (2004:35) "the survival of traditional knowledge is vital to ensure sustainable conservation of [natural] resources in Melanesia". Therefore, traditional knowledge involving, but not limited to, herpetofauna requires active documentation and preservation to facilitate biodiversity conservation objectives, sustainable resource use, and sustainable societies, especially at the community level. There is a strong need for conservation of both biodiversity and its interrelated traditional knowledge (Keppel et al. 2012; Pollard et al. 2014).

The present study documented a difference in traditional knowledge held according to age, with the younger generation $(<30$ years) demonstrating less knowledge than the oldest generation ( $>60$ years). Similar findings were encountered by Lohani (2011) 
Table 3. Descriptive summary of 'Are'Are uses of herpetofauna.

\begin{tabular}{|c|c|}
\hline Species & Detailed uses \\
\hline Discodeles guppyi & $\begin{array}{l}\text { Food: This frog was an important protein component in bush diets. It was especially eaten } \\
\text { during feasts and usually cooked by roasting. It was usually hunted during rains by listening } \\
\text { for its call. March is said to be the best month to catch this frog. Informants reported that } \\
\text { snapping a twig when encountering this frog will render it immobile, as it will think one of } \\
\text { its legs has broken. Another technique involved using a whistle made from a stick that pro- } \\
\text { duces a sound to which this frog responds. It was also eaten by domestic dogs and cats. To- } \\
\text { temic: It was considered a totem to certain tribes and believed to bring fertility to gardens if } \\
\text { present. Consumption of this frog was prohibited by tribes holding this belief. Medicine: } \\
\text { Bones of this frog were rubbed against children's bodies to prevent snake and centipede } \\
\text { bites. }\end{array}$ \\
\hline Batrachylodes vertebralis & $\begin{array}{l}\text { Food: This frog was eaten, sometimes being cooked in bamboo stems. Traditionally an im- } \\
\text { portant food for feasts, an auapu (important woman) would eat it to signify that feasting } \\
\text { may begin. Trade: This highly valued species, with seasonal harvesting taboos, was traded } \\
\text { and could be bought with pata-ni-hanua (traditional shell money). Folklore: If its legs were } \\
\text { broken when caught, a tree was believed to fall on you in the forest. }\end{array}$ \\
\hline Ceratobatrachus guentheri & $\begin{array}{l}\text { Food: This frog was gutted before being roasted and consumed as an important feast food. } \\
\text { Magic: The bones were reported to be used in mato'oha (sorcery) to bring luck and to in- } \\
\text { crease garden fertility. Medicine: The species was also used as a medicine for opa-opo } \\
\text { (swollen stomach) and to treat bedwetting in children by rubbing against the child's stom- } \\
\text { ach. Its urine was also drunk to heal stomach illnesses. Its saliva could be used to treat snake } \\
\text { and centipede bites. Folklore: In one traditional story, this frog was responsible for pro- } \\
\text { tecting an area in the mountains from being destroyed by black magic, as evidenced by the } \\
\text { presence of a distinctive uphill jutting, known as Hurakaia. }\end{array}$ \\
\hline \multirow[t]{2}{*}{ Platymantis guppyi } & $\begin{array}{l}\text { Food: This frog was caught in traps made from folded leaves, roasted, and eaten. It was also } \\
\text { preyed upon by snakes. Trade: The species was used in trade, exchange, and commerce. } \\
\text { Medicine: It was used to prevent bedwetting by rubbing the frog on a child's stomach or } \\
\text { making the frog urinate on a child's head. Totemic: This frog was regarded as a koe maea } \\
\text { (taboo frog) and was considered a totem to certain tribes, with its call believed to signal } \\
\text { death if found calling near a house. }\end{array}$ \\
\hline & $\begin{array}{l}\text { Food: This frog was eaten. Totemic: Some tribes were not allowed to eat this frog, as it was } \\
\text { their totem and could signal death or sickness if heard calling or found in the house. It was } \\
\text { also used to determine the thoughts and feelings of ancestral spirits. Fishing: Juvenile frogs } \\
\text { were used as bait for catching eels. }\end{array}$ \\
\hline Platymantis weberi & Food: This frog was eaten. \\
\hline Platymantis solomonis & Food: This frog was eaten. \\
\hline Litoria thesaurensis & $\begin{array}{l}\text { Food: This frog was eaten and is also preyed upon by cats and snakes. Medicine: This frog } \\
\text { was used to rub against a child's stomach to prevent bed-wetting. }\end{array}$ \\
\hline Emoia pseudocyanura & $\begin{array}{l}\text { Food: This lizard was opportunistically hunted, often being roasted and eaten. Fishing: It was } \\
\text { used as fishing bait. Medicine: It was used by young boys to rub against their faces and } \\
\text { thereby prevent facial hair growth. }\end{array}$ \\
\hline
\end{tabular}

(continued on next page) 
(continued from previous page)

\begin{tabular}{|c|c|}
\hline Species & Detailed uses \\
\hline Corucia zebrata & $\begin{array}{l}\text { Food: This lizard was hunted and eaten, being considered to have tasty greasy meat. Alt- } \\
\text { hough an important source of protein in the past, it is now becoming rare. Magic: This lizard } \\
\text { was also used in sacrifices for ancestral worship. Folklore: This lizard was said to cohabit with } \\
\text { the opossum (Phalanger orientalis Pallas Phalangeridae), which is said to be its natural ene- } \\
\text { my. }\end{array}$ \\
\hline Gehyra oceanica & $\begin{array}{l}\text { Food: This lizard could be eaten. Magic: This gecko was used as a good-luck charm for gam- } \\
\text { bling. }\end{array}$ \\
\hline Cyrtodactylus salomonensis & $\begin{array}{l}\text { Food: This lizard could be eaten and was an important feast food. Folklore: Disobedient chil- } \\
\text { dren would often be frightened by parents, who old them that if disobedient, their eyes } \\
\text { would turn into the eyes of a rarani. It was also claimed that this lizard had the ability to find } \\
\text { gold. Trade: Currently, this lizard is valued in Honiara at around SBD\$500 for sale in the ex- } \\
\text { otic pet trade. A few men have devised traps to catch this lizard. }\end{array}$ \\
\hline Eugongylus albofasciolatus & $\begin{array}{l}\text { Food: This lizard could be eaten and was usually cooked in bamboo leaves. Totemic: It is a } \\
\text { totem for some tribes, signalling death. If encountered, certain evil spirits were believed to } \\
\text { take the form of this lizard, causing childbirth difficulties and insanity in victims. }\end{array}$ \\
\hline Prasinohaema virens & Food: This lizard could be eaten. Fishing: It was used as fishing bait. \\
\hline Sphenomorphus bignelli & Fishing: This lizard was used as fishing bait. \\
\hline Emoia atrocostrata & $\begin{array}{l}\text { Fishing: This lizard was used as fishing bait. Totemic: It was a totem and taboo animal for } \\
\text { certain tribes, being used in traditional sacrifices. }\end{array}$ \\
\hline Emoia cyanogaster & $\begin{array}{l}\text { Food: This lizard could be eaten and was also preyed upon by cats, birds, and snakes. Sor- } \\
\text { cery: The bones were used as good luck charms in gambling. }\end{array}$ \\
\hline
\end{tabular}

and Cruz-Garcia (2006), who reported younger people had less knowledge than older people of animals and their traditional uses. In these previous studies, the reasons mentioned for reduced knowledge among younger participants included: 1) decreased "knowledge transmitting events" and interactions between the older and younger generations, which is also a plausible reason for the 'Are'Are situation, although we did not collect information on this issue (Cruz-Garcia 2006; Lohani 2011); 2) decreased availability or increasingly threatened status of wild food plants and animals, which may also applicable to the 'Are'Are; 3) social stigmatization by which TEK is viewed as unimportant and leads to lack of interest among younger people; and 4) school attendance, which limits time for traditional knowledge acquisition (Cruz Garcia 2006; Lohani 2011). School attendance, potentially limiting TEK acquisition time, occurs on Malaita, where children attend mission schools based in coastal communities.
Because TEK generally may grow and expand through time, space, and experiences, we assume that as individuals get older their knowledge will also increase. The reduced knowledge in younger generation documented in the present study may therefore be the result of fewer learning experiences, not necessarily because knowledge is being lost. This may also result in a shift in TEK distribution, whereby younger generations have greater in-depth knowledge and experience regarding coastal landscapes, in contrast to forest landscapes, where the majority of terrestrial herpetofauna are found. For example, a study focusing on marine TEK might find that younger people have greater knowledge than older individuals.

The current study found that most TEK was held by older informants, especially those who spent a significant part of their lives in forest or inland habitats, as opposed to those who grew up in coastal settlements. Our results show that TEK, although 
likely threatened, also persists, continues to be produced, and thrives through application (i.e., if TEK ceases to be applied, both it and associated biodiversity may be lost) (Charnley et al. 2007). As Thaman (2013:23) stressed in relation to the loss of traditional taxonomic expertise and the conservation of threatened species, "if we can't name them and don't know them, we may lose them." Conversely, if species are disappearing, the knowledge will disappear with them in a negative feedback loop. If traditional knowledge and practices involving herpetofauna cease to be practiced and shared, associated oral information may also be threatened with extinction. For example, methods of capturing and cooking frogs could be lost along with the traditional customs and stories that mention them. The conservation of biological species and their associated TEK must therefore be considered of equal importance.

Recuperating the citation from E. O. Wilson at the opening of this paper, the sixth biodiversity extinction crisis is clearly upon us (Wilson 1992). Paralleling this biological phenomenon is an ethnobiodiversity extinction crisis involving a loss of TEK and associated taxonomic expertise that may be more serious for humanity than the actual extinction of biological taxa. This is a somewhat hidden crisis that undermines attempts at community conservation as a basis for sustained human wellbeing, particularly for rural biodiversity-dependent and landowning communities, such as those of the 'Are'Are in the Solomon Islands.

\section{Acknowledgments}

We thank the people of 'Are'Are, who are custodians of their traditional ecological knowledge and shared the richness of this knowledge with us. We also thank the translators and guides who helped us administer the questionnaire.

\section{Declarations}

Permissions: None Declared.

Sources of Funding: The University of the South Pacific Research Office and the FSTE Research Committee provided the funds supporting this research.

Conflicts of Interest: None declared.

\section{References Cited}

Alves, R., W. Vieira and G. Santana. 2008. Reptiles Used in Traditional Folk Medicine: Conservation Implications. Biodiversity Conservation 17:2037-2049.
Bennet, J. A. 2000. Pacific Forest: A History of Resource Control and Contest in Solomon Islands, c. 1800-1997. The White Horse Press, Cambridge, United Kingdom.

Bennett, D. 1999. Reptiles and Amphibians: Expedition Field Techniques. Expedition Advisory Centre, London.

Berkes, F. 2004. Rethinking Community-Based Conservation. Conservation Biology 18:621-630.

Bombi, P. 2009. Toward a New Instrument for Identifying the Italian Hotspots of Biodiversity: A Case Study of the Amphibians and Reptiles of Sicily. Italian Journal of Zoology 77:453-459.

Bishop, P.J., A. Angulo, J. P. Lewis, R.D. Moore, G. B. Rabb and J. Garcia Moreno. 2012. The Amphibian Extinction Crisis - What Will It Take to Put the Action into the Amphibian Conservation Action Plan? S.A.P.I.EN.S. Available at: http:// sapiens.revues.org/1406. Accessed on January 13, 2014.

Brosius, J. P. and S. L. Hitchner. 2010. Cultural Diversity and Conservation. International Social Science Journal 61:141-168.

Caillaud, A., S. Boengkih, E. Evans-Illidge, J. Genolagani, P. Havemann, D. Henao, E. Kwa, D. Llewell, A. Ridep-Morris, J. Rose, R. Nari, P. Skelton, R. South, R. Sulu, A. Tawake, B. Tobin, S. Tuivanuavou and C. Wilkinson. 2004. Tabus or not Taboos? How to Use Traditional Environmental Knowledge to Support Sustainable Development of Marine Resources in Melanesia. SPC Traditional Marine Resource Management and Knowledge Information Bulletin. The Secretariat of the Pacific Community, Suva.

Charnley, S., A. P. Fischer and E. T. Jones. 2007. Integrating Traditional and Local Ecological Knowledge into Forest Biodiversity Conservation in the Pacific Northwest. Forest Ecology and Management 246:14-28.

Cloudsley-Thompson, J. L. 1999. The Diversity of Amphibians and Reptiles: An Introduction. Springer, Berlin, Germany.

Cruz Garcia, G. 2006. The Mother - Child Nexus. Knowledge and Valuation of Wild Food Plants in Wayanad, Western Ghats, India. Journal of Ethnobiology and Ethnomedicine 2:39. 
Dutfield, G. 2006. Protecting Traditional Knowledge: Pathways to the Future. International Centre for Trade and Sustainable Development (ICTSD), Geneva, Switzerland.

FAO. 2011. State of the World's Forests. Food and Agriculture Organization of the United Nations, Rome, Italy.

Filardi, C. E., Boseto, D. and Filardi, C. E. 2007. A preliminary Desk Study Identifying Important Bird Areas (IBAs) in the Solomon Islands. BirdLife International, Cambridge, United Kingdom.

Gough, K. V., T. Bayliss-Smith, J. Connell and O. Mertz. 2010. Small Island Sustainability in the Pacific: Introduction to the Special Issue. Singapore Journal of Tropical Geography 31:1-9.

Huntington, H. P. 2000. Using Traditional Ecological Knowledge in Science: Methods and Applications. Ecological Applications 10:1270-1274.

Hviding, E. 2005. Reef and Rainforest: An Environmental Encyclopedia of Marovo Lagoon, Solomon Islands. UNESCO: Paris, France.

IUCN. 2013. IUCN Red List of Threatened Species. www.iucnredlist.org.

Keesing, R. M. 1967. Christians and Pagans in Kwaio, Malaita. The Journal of the Polynesian Society 76:82-100.

Keppel, G., C. Morrison, D. Watling, M. Tuiwawa and I. Rounds. 2012. Conservation in Tropical Pacific Island Countries: Why Most Current Approaches are Failing. Conservation Letters 5:256265.

Lauer, M. and S. Aswani. 2010. Indigenous Knowledge and Long-term Ecological Change: Detection, Interpretation, and Responses to Changing Ecological Conditions in Pacific Island Communities. Environmental Management 45:985-997.

Lohani, U. 2011. Traditional Uses of Animals Among Jirels of Central Nepal. Studies on Ethno-Medicine 5:115-124.

McCoy, M. 2006. Reptiles of the Solomon Islands. Pensoft Publishers, Sofia, Bulgaria.

Moore, C., 2007. The Misappropriation of Malaitan Labour: Historical Origins of the Recent Solomon Islands Crisis. Journal of Pacific History 42:211-232.

Merculieff, L., 2000. Linking Traditional Knowledge and Wisdom to Ecosystem Based Approaches in
Research and Management. In Ethnobiology and Biocultural Diversity edited by J. R. Stepp, F. S. Wyndham and R. K. Zarger. International Society of Ethnobiology, Athens, GA.

Mueller-Dombois, D. and F. R. Fosberg. 1998. $V$ egetation of the Tropical Pacific Islands. SpringerVerlag, New York City, NY.

PHCG. 2008. Solomon Islands State of Environment Report 2008. Pacific Horizon Consultancy Group, Honiara, Solomon Islands.

Pikacha, P., C. Morrison and S. Richards. 2008. Frogs of the Solomon Islands. Institute of Applied Sciences, The University of the South Pacific, Suva, Fiji.

Polhemus, D. A., R. A. Englund, G. R. Allen, D. Boseto and J. T. Polhemus. 2008. Freshwater Biotas of the Solomon Islands: Analysis of Richness, Endemism and Threats. Bishop Museum Press Technical Report 45, Honolulu, HI.

Pollard, E. J. M. 2014. Evaluating Tropical Forest Ecosystems: Using Herpetofauna and Culture to Determine Conservation Priority Habitats on Malaita Island, Solomon Islands. Master's Thesis, School of Geography, Earth Science and Environmental Sciences, University of the South Pacific, Suva, Fiji.

Pollard, E., G. Brodie, R. Thaman, and C. Morrison. 2014. The Use of Herpetofauna and Cultural Values to Identify Priority Conservation Forests on Malaita, Solomon Islands. Pacific Conservation Biology 20:354362.

Pough, F. H., R. M. Andrews, J. E. Cadle, M. L. Crump, A. H. Savitzky and K. D. Wells. 1998. Herpetology. Prentice-Hall, Inc., Upper Saddle River, NJ.

SINSO. 2011. Report on 2009 Population \& Housing Census. Statistical Bulletin 06/2011. Solomon Islands National Statistics Office, Solomon Islands Government, Honiara.

Smith, W. H. and L. J. Rissler. 2010. Quantifying Disturbance in Terrestrial Communities: Abundance -Biomass Comparisons of Herpetofauna Closely Track Forest Succession. Restoration Ecology 18:195204.

Stuart, S. N., J. S. Chanson, N. A. Cox, B. E. Young, A. S. L. Rodrigues, D. L. Fischman and R. W. Waller. 2004. Status and Trends of Amphibian 
Declines and Extinctions Worldwide. Science 306:1783-1786.

Thaman, R. R. 2002. Threats to Pacific Island Biodiversity and Biodiversity Conservation in the Pacific Islands. Development Bulletin 58:23-27.

Thaman, R. R. 2008a. A Matter of Survival: Pacific Islands' Vital Biodiversity, Agricultural Biodiversity and Ethno-biodiversity Heritage. Pacific Ecologist 16:53-61.

Thaman, R. R. 2008b. Pacific Island Agrobiodiversity and Ethnobiodiversity: A Foundation for Sustainable Pacific Island Life. Biodiversity: Journal of Life on Earth 9:102-110.

Thaman, R.R. 2009. Sustainability. In Encyclopedia of Islands, edited by R. G. Gillespie, pp. 888-896. University of California Press, Berkeley, CA.

Thaman, R. R., Puia, T., Tongabaea, W., Namona, A. and T. Fong. 2010. Marine Biodiversity and Ethnobiodiversity of Bellona (Mungiki) Island, Solomon Islands. Singapore Journal of Tropical Geography 31:70-84.

Thaman, R.R. 2013. Ethno-biodiversity, Taxonomy and Bioinformatics for All Ages: Engaging and Educating the Next Generation of Taxonomists as a Foundation for Sustainable Living on Planet earth - Challenges and Opportunities. In Tracking Key Trends in Biodiversity Science and Policy: Based on the Proceedings of a UNESCO International Conference on Biodiversity Science and Policy, edited by L. A. Brooks and S. Aricò, pp. 23-25. UNESCO, Paris, France.
Walker-Painemilla, K., A. B. Rylands, A. Woofter and C. Hughes. 2010. Indigenous Peoples and Conservation: From Rights to Resource Management. Conservation International, Arlington, VA.

Wilson, E.O. 1992. The Diversity of Life. Harvard University Press, Cambridge, United Kingdom.

Supplementary Files available at ojs.ethnobiology.org/ index.php/ebl.

\section{Biosketches}

Edgar J. M. Pollard's expertise and interests include biodiversity and conservation, herpetofauna, use and documentation of traditional ecological knowledge and Pacific histories and cultures.

Randy Thaman is an Emeritus Professor of Pacific Islands Biogeography at the University of the South Pacific. Areas of expertise are ethnobiology, conservation, sustainable island development, biodiversity, agroforestry, food systems, and traditional environmental knowledge.

Gilianne Brodie is an Associate Professor in Biology at the University of the South Pacific. Areas of expertise are island biodiversity, conservation, invertebrates, taxonomy and merging traditional indigenous knowledge into mainstream science, and natural resource management.

Clare Morrison is a Research Fellow in the School of Environment, Griffith University. Areas of expertise are conservation, herpetofauna, taxonomy, local capacity building, and sustainable use of natural resources. 